\title{
PENGEMBANGAN BLOG BUDAYA SEBAGAI SARANA BELAJAR BUDAYA
}

\author{
Dyah Prasetiani \\ Universitas Negeri Semarang \\ Email : prasetiani.dyah@gmail.com
}

\begin{abstract}
Indonesia is a country that has a diverse culture, ethnicity, language, and rich tourism potentials. However, many people abroad who do not know about the diversity of Indonesian culture. The younger generations were much less aware of even less have sufficient of the richness of the culture of Indonesia. The knowledge about Indonesian culture of Japanese Language Education students Semarang State University, is still inadequate, so they can not be explained to the Japanese society apropiately, not good enough. Therefore students need to be given education by developingblog that contains Indonesian culture which is written in Japanese. The purpose of this study was developing a blog that can be a means of learning the culture. The method used is the Research and Development $(R \& D)$, with a step preliminary studies, product development, and product validation testing. Data was collected by questionnaire. Japanese expert validation results towards this blogare considered quite good as a means of studying Indonesian culture with an average score of 2.7 on the aspects of the format, quality, clarity, and clarity of language.
\end{abstract}

Keywords: blog, culture, Japanese

\section{PENDAHULUAN}

Indonesia adalah negeri yang memiliki beragam budaya, suku bangsa, bahasa, serta kaya akan potensi wisatanya. Namun masih banyak orang luar negeri yang tidak mengetahui tentang budaya Indonesia. Nampaknya upaya memperkenalkan budaya Indonesia pada masyarakat luar negeri masih belum cukup. Ditambah dengan kondisi yang terjadi di Indonesia saat ini yaitu budaya lokal agak terlupakan oleh generasi muda dikarenakan perkembangan zaman dan pengaruh budaya asing yang masuk di Indonesia,

Kondisi yang sama juga dinyatakan oleh Masanori Nagaoka, Program Specialist UNESCO OfficeJakarta, dalam acara jumpa pers Pelatihan dan Pendidikan Warisan Budaya untuk Kaum Muda
Indonesia. Rabu (26/11) di Jakarta Menurutnya "Rasa bangga dan kepedulian melestarikan budaya kurang tertanam di generasi muda Indonesia saat ini. Minat mereka untuk mempelajarinya kurang. Mereka lebih tertarik belajar kebudayaan asing. Salah satu factor penyebabnya adalah kurangnya informasi kekayaan yang dimiliki Bangsa Indonesia" (Kompas online, 2008).

Kondisi ini pun penulis temui ketika mengobservasi mahasiswa semester I Prodi Pendidikan Bahasa Jepang Unnes, pada saat mengikuti perkuliahan Pengantar Ilmu Budaya. Pengetahuan tentang budaya Indonesia mereka masih kurang memadai, sehingga mengalami kesulitan ketika harus menjawab pertanyaan yang diajukan dalam diskusi. 
Izumi, Volume 5, No 2, 2016

e-ISSN: 2502-3535, p-ISSN: 2338-249X

Tersedia online di http://ejournal.undip.ac.id/index.php/izumi

Kurangnya pengetahuan dan kesadaran generasi muda terhadap budaya sendiri lambat laun dapat berdampak pada punahnya budaya Indonesia. Karena itu mereka perlu diberi edukasi serta sarana agar mampu memperkenalkan budaya Indonesia pada orang lain. Salah satu cara yang dapat dilakukan adalah dengan mengembangkan sebuah blog tentang budaya Indonesia yang dapat dijadikan sarana belajar budaya bagi penggunanya.

Blogpada hakikatnya merupakan media menulis berbasis internet. Pembuatan blog lebih mudah dibandingkan dengan website, karena kebanyakan blog berinduk pada penyedia blog seperti blogger.com, wordpress.com, weblog.com, atau multiply.com yang menyediakan TEMPLATE-TEMPLATE yang siap pakai dan tidak menuntut kemahiran teknis, estetik, atau perancangan dari penggunanya.

Disamping itu blogjuga lebih mudah dalam hal pengelolaannya. Kegiatan mengedit, mengganti, memperbaharui isiblog, mengunggah foto atau video juga relatif mudah dan dapat dilakukan kapan saja, asalkan memiliki akses internet.

Saat ini blog juga dapat diisi dengan audio (podcast) serta video (vlogs). Dengan demikian, pemilik dapat mengunggah berbagai multi media kedalam blognya, seperti lukisan dalam deviant art (www.deviantart.com), video dalam YouTube (www.youtube.com), file slide dan PDFs dalam SlideShare (www.slideshare.net) dan foto kedalam Flickr. (www.flickr.com).

Dalam dunia pendidikan tinggi, para peneliti dan pendidik terinspirasi untuk memanfaatkan blog sebagai media pembelajaran sejak 2005 (Downes, 2004). Blogdan fitur-fiturnya sangat potensial digunakan sebagai sarana untuk mewujudkan tujuan utama, yakni: membantu mahasiswa mengembangkan ilmu pengetahuan di bidang yang dipilihnya; memfasilitasi mahasiswa untuk mengembangkan teknik berpikir kritis, logis, kemahiran berkomunikasi (lisan dan tulisan); dan mendorong mahasiswa menjadi pemikir dan pembelajar yang mandiri serta mampu bekerjasama (Allan, 1996).

Dengan demikian Blog dapat dijadikan sarana belajar yang interaktif dikarenakan didesainnya dapat dibuat menarik.

Sehingga pembelajar akan tertarik menggunakannya sebagai sumber belajar, termasuk belajar budaya.

\section{METODE PENELITIAN}

Untuk membuat sebuah blog yang baik, penulis melakukan penelitian terlebih dahulu. Langkah-langkah yang penulis tempuh adalah tiga tahap dalam penelitian research and development, yakni melakukan studi pendahuluan, mendesain produk, dan uji validasi produk.

Populasi yang penulis gunakan dalam studi pendahuluan adalah mahasiswa Program Studi Pendidikan Bahasa Jepang Universitas Negeri Semarang. Sedangkan sampel penelitian ini adalah 20 mahasiswa Program Studi Pendidikan Bahasa Jepang Universitas Negeri Semarang semester II. Penentuan subjek penelitian ini dilakukan dengan cara random sampling.

Pengumpulan data dilakukan dengan memberikan kuesioner dan wawancara pada responden. Serta memberikan angket pada ahli bahasa Jepang untuk uji validasi blog. Data hasil angket dihitung secara kuantitatif, kemudian dianalisis secara kualitatif. 
Izumi, Volume 5, No 2, 2016

e-ISSN: 2502-3535, p-ISSN: 2338-249X

Tersedia online di http://ejournal.undip.ac.id/index.php/izumi

\section{HASIL DAN PEMBAHASAN}

\section{Hasil Analisis Kebutuhan}

Studi pendahuluan yang dilakukan pada tanggal 17 Juni 2016 terhadap 20 responden mahasiswa dengan tujuan untuk mengumpulkan informasi tentang kebutuhan akan penyediaan blog budaya Indonesia berbahasa Jepang, menghasilkan data sebagai berikut:

Tabel 1. Ketersediaan informasi budaya Indonesia di internet

\begin{tabular}{|c|l|c|c|}
\hline No & \multicolumn{1}{|c|}{ Pertanyaan } & Jawab & $\mathrm{F}$ \\
\hline 6 & $\begin{array}{l}\text { Apakah Anda menemukan website tentang budaya } \\
\text { Indonesia berbahasa Jepang di internet }\end{array}$ & Belum & 14 \\
\hline
\end{tabular}

Sebanyak 14 respondenmahasiswa (sekitar 70\%) mengatakan belum menemukan website tentang budaya Indonesia berbahasa Jepang di internet. Jawaban ini telah menguatkan tujuan penulis untuk mengembangkan sebuah blog budaya Indonesia berbahasa Jepang.

Karena responden menjawab belum menemukan website tentang budaya Indonesia, maka penulis lebih lanjut menanyakan bentuk media penyampaian yang dinginkan oleh responden.Merekamemberikan jawaban yang beragam, namunjawabanterbanyak (dijawaboleh 7 responden) menginginkan tersedianyainformasibudaya Indonesiadalambentukblog, website, media sosial, iklan, dan video. Jawaban ini dapat dilihat pada tabel berikut:

Tabel 2. Bentuk informasi budaya Indonesia yang diinginkan

\begin{tabular}{|c|c|c|c|}
\hline No & Pertanyaan & Jawaban & $F$ \\
\hline \multirow[t]{11}{*}{12} & \multirow{11}{*}{$\begin{array}{l}\text { Bilaperlu, sebaiknya } \\
\text { dalam bentuk apa? }\end{array}$} & Blog,website,medsos, iklan, video & 7 \\
\hline & & - (tidakmenjawab) & 3 \\
\hline & & Artikel di internet & 1 \\
\hline & & Mading, poster, bulletin & 1 \\
\hline & & Komikdengancerita yang seru & 1 \\
\hline & & Poster yang dishare di medsos/ bentukkomunitas & 1 \\
\hline & & Video, essai, site internet, pementasan & 1 \\
\hline & & E book agar mudahdidapatdanpraktis & 1 \\
\hline & & Buku, makalah, karangan & 1 \\
\hline & & Tulisan & 1 \\
\hline & & Kanji danadafurigananya & 1 \\
\hline
\end{tabular}

Dari tabel di atas dapat diketahui bahwa sebanyak 7 responden (sekitar 35\%) menginginkan tersedianya informasi dalam bentuk blog, website,medsos, iklan, video. Responden juga memberikan jawaban ingin tersedia informasi tentang budaya Jepang dalam bentuk mediasosial. Maksudnya yakni agar informasi tersebut mudah diakses melalui handphone dan dapat dishare kepada siapapun yang mereka inginkan. Karena itu disimpulkan oleh penulis bahwa responden menginginkan tersedianya informasi budaya Indonesia dalam bentuk blog/website yang dilengkapi dengan iklan dan video agar mudah diakses dan menarik.

Sedangkan untuk saran bentuk blog yang diinginkan, setiap responden memberikan jawaban yang berbeda. Dan hanya satu responden yang tidak memberikan jawaban. Sementara 19 responden memberikan jawaban. Adapun jawaban responden adalah sebagai berikut: 
Izumi, Volume 5, No 2, 2016

e-ISSN: 2502-3535, p-ISSN: 2338-249X

Tersedia online di http://ejournal.undip.ac.id/index.php/izumi

Tabel 3. Saran responden

\begin{tabular}{|c|c|c|c|}
\hline No & Pertanyaan & Jawaban & $\mathrm{F}$ \\
\hline \multirow[t]{10}{*}{13} & \multirow{10}{*}{$\begin{array}{l}\text { Bila informasi } \\
\text { tersebutdibuat } \\
\text { dalam } \\
\text { bentuk........., } \\
\text { Tuliskan saran } \\
\text { Anda, } \\
\text {.........seperti apa } \\
\text { yang Anda } \\
\text { inginkan? }\end{array}$} & Disertai foto dan video agar lebih menarik & 2 \\
\hline & & Terlihat menarik dan tidak membosankan & 1 \\
\hline & & Blog yang menarik dengan memperhatikan isi blog & 1 \\
\hline & & Blog bilingual. Ditambah foto dan video & 1 \\
\hline & & $\begin{array}{l}\text { Berisitentangbudaya Indonesia yang menarik, teladan, dan } \\
\text { mendalam namun tanpa campuran bahasa dari negara lain }\end{array}$ & 1 \\
\hline & & $\begin{array}{l}\text { Blog yang menawarkansesuatu yang unik. Seperti adanya kuis } \\
\text { di setiap minggu dan ada poin }\end{array}$ & 1 \\
\hline & & Ragam budaya Indonesia & 1 \\
\hline & & $\begin{array}{l}\text { Blog tersebut didekorasiwarna-warni agar lebihm enarik, dan } \\
\text { warna utamanya adalah ungu agar lebih menjunjukkan rasa } \\
\text { cinta PBJ FBS dan agar lebih menarik. }\end{array}$ & 1 \\
\hline & & $\begin{array}{l}\text { Blog yang isinya lengkap (dasar-dasar berbahasa Jepang, } \\
\text { budaya Jepang) }\end{array}$ & 1 \\
\hline & & $-\quad($ tidakmenjawab $)$ & 1 \\
\hline
\end{tabular}

Secara singkat dapat dikatakan bahwa 4 responden (20\%) menginginkan blog yang menarik dan tidak membosankan, menarik isinya dengan disertai foto dan video. Sedangkan responden lainnya memberikan saran blog tersebut dibuat berwarna-warni dengan warna dasar ungu untuk menunjukkan identitas pembuatnya dari FBS Unnes (namun hal ini tidak mutlak harus diberi warn ungu). Terdapat hal yang menarik yakni satu responden menginginkan blog bilingual, namun sebaliknya terdapat satu responden yang menyarankan jangan bilingual.

Responden yang memberikan jawaban "ingin blog yang bilingual", sempat peneliti konfirmasi dalam sebuah wawancara. Penjelasan yang diberikan responden yaitu ternyata ia menginginkan tersedianya blog yang tidak hanya bilingual melainkan multi lingual, ditulis dalam 3 bahasa yakni Indonesia, Jepang dan Inggris agar dapat dipahami oleh seluruh pembaca dari mancanegara. Berikut kutipan wawancaranya:
T: “ Saran dariAnda, blog seperti apa yang Anda inginkan?"

J: "Ya, blog yang memuat budaya Indonesia lengkap dari Sabang sampe Merauke dengan bantuan tiga bahasa Indonesia, Jepang dan Inggris, kenapa? Ya karena secara basic bahasa Inggris bisa dipahami seluruh dunia gitu."

Dengan demikian dapat disimpulkan bahwa responden menganggap perlu dibuat sebuah blogyang berisi informasi tentang budaya Indonesia yang ditulis dalam 3 bahasa yakni Indonesia, Jepang, dan Inggris agar dapat dibaca oleh semua pengguna internet yang terdapat di Indonesia maupun mancanegara. Responden juga menginginkan blog yang menarik, tidak membosankan, isinya/informasinya lengkap, berwarna, ada foto, dan bila perlu ada video/vlog. 
Izumi, Volume 5, No 2, 2016

e-ISSN: 2502-3535, p-ISSN: 2338-249X

Tersedia online di http://ejournal.undip.ac.id/index.php/izumi

\section{Desain Dan Konten Blog Budaya}

Berdasarkan hasil kuesioner dan wawancara pada studi pendahuluan, maka dibuatlah desainawalblog budaya Indonesia berbahasa Jepang seperti yang dapat dilihat pada gambar di bawah ini.

Gambar 1. Desain awal blog

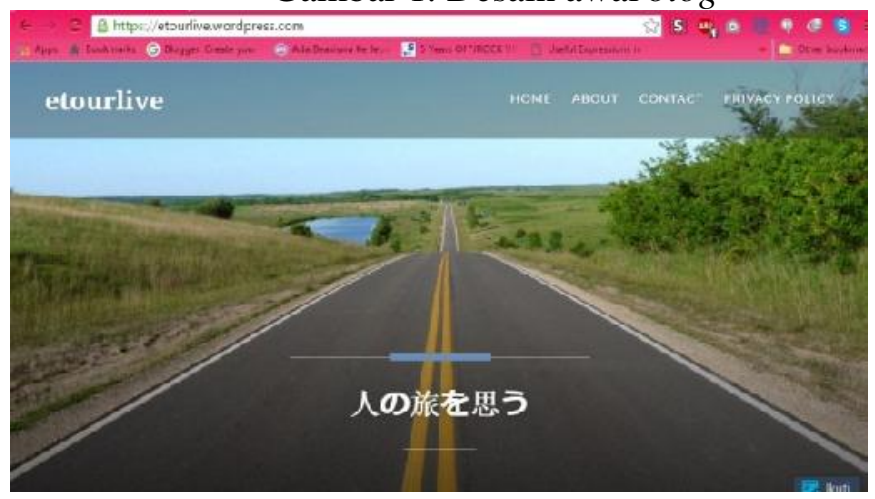

Konten Blog budaya yang dikembangkan oleh penulisberisi tentang informasi budaya dan tempat wisata yang ada di Semarang dan sekitarnya (Jawa Tengah). Karena itu artikel yang diunggah adalah tentang museum kereta api Ambarawa dan tempat wisata Eling Bening di Ambarawa. Artikel tersebut disertai fotofoto yang merupakan foto original dari tim peneliti.

Blog ini ditulis dalam bahasa Indonesia, Inggris, dan Jepang, dengan tujuan dapat meraih cakupan pembaca yang lebih luas. Pemilihan multilingual ini didasarkan pada masukan dari responden mahasiswa. Sehingga diharapkan Blog ini diharapkan dapat menjadi sumber belajar budaya bagi orang Indonesia, Jepang, maupun orang asing lainnya.

\section{Hasil Uji Validasi Produk}

Produk yang dihasilkan melalui penelitian ini adalah blog budaya Indonesia yang ditulis dalam bahasa Indonesia, Inggris, dan Jepang. Untuk mengetahui kelemahan dan kekuatan produk ini maka tim peneliti melakukan uji validasi kepada ahli bahasa Jepangdengan mengunakan instrumen kuesioner.
Hasil yang diperoleh yaitu menurut ahli bahasa Jepang, blog dinilai cukup dengan rata-rata skor 2,7. Penilaian ini ditinjau dari segi format blog, kualitas blog, kejelasan isi, dan kejelasan bahasa. Kekuatan blog dikatakan terdapat pada warna serta foto yang digunakan dalam blog sudah cukup baik. Sedangkan kelemahan blog dikatakan terdapat pada kuantitas artikel yang memang masih baru terunggah 2 artikel. Meski secara kualitas isi artikel dinilai cukup memberikan informasi tentang budaya dan lokasi wisata di Semarang.

\section{KESIMPULAN}

Kesimpulan yang dapat diambil dari penelitian ini adalah:

Hasil analisis kebutuhan mahasiswa menunjukkan bahwa blog budaya Indonesia berbahasa Jepang dibutuhkan sebagai media informasi bagi pembelajar Indonesia yang sedang belajar bahasa Jepang dalam upaya memperkaya wawasan untuk memperkenalkan budaya Indonesia pada orang Jepang.

Hasil validasi ahli bahasa Jepang mengatakan bahwa blog sudah cukup baik dari segi format, kualitas, kejelasan isi, dan kejelasan bahasa dengan rerata skor 2,7 
Izumi, Volume 5, No 2, 2016

e-ISSN: 2502-3535, p-ISSN: 2338-249X

Tersedia online di http://ejournal.undip.ac.id/index.php/izumi

\section{DAFTAR PUSTAKA}

Allan.(1996). Learning Outcomes in Higher Education" in STUDIES IN HIGHER EDUCATION, Vol. 21, 1996, pp. 93108.

Blog. (2011). Retrieved on October 17, 2011 from http://en.wikipedia.org/wiki/Blog

Davenport, T. H. \& L. Prusak. (1998). Working Knowledge: How Organizations Manage What They Know. Boston, MA: Harvard Business School Press. [on-line] Available from: http://www.educause.edu/ir/library/p df/erm0450.pdf

Downes, S. (2004). Educational Blogging, EDUCAUSE, September / October, 14-26. Available at http://net.educause.edu/ir/library/pdf/ ERM0450.pdf

Koentjaraningrat. 1993. Kebudayaan, Mentalitet, dan Pembangunan. Jakarta: PT Rineka Cipta

Sugiyono. 2006. Metode Penelitian Pendidikan. Bandung: Alfabeta
Pardede, Parlindungan. (2011).BLOG Sebagai Media Pembelajaran dan Alat Pengelolaan serta Pengembangan Ilmu di Perguruan Tinggi. http://parlindunganpardede.com. (Oct 21, 2011).Diunduh 14 Maret 2016

Williams, J. B \& Jacobs, J. (2004) Exploring the Use of Blogs as Learning Spaces in theHigher Education Sector. AUSTRALASIAN JOURNAL OF EDUCATIONAL TECHNOLOGY 2004, 20(2), 232-247.

Davenport, T. H. \& L. Prusak. (1998). Working Knowledge: How Organizations Manage What They Know. Boston, MA: Harvard Business School Press. [on-line] Available from: http://www.educause.edu/ir/library/p df/erm0450.pdf

Generasi Muda Kurang Peduli Budaya Sendiri - Kompas.com. 26 Nov 2008. http://nasional.kompas.com/read/2 008/11/26/17323361/generasi.muda. kurang.peduli.budaya.sendiri. Diunduh 28 Februari 2016. 